\title{
The Immigrant-native Student Educational Achievement Gap in Greece using PISA 2012
}

\author{
By Chris Sakellariou*
}

\begin{abstract}
Starting in the 1970s Greece, a traditional emigration country, experienced an immigration boom, with the majority of immigrants being Albanians and co-ethnic Greeks from the ex-Soviet Union and other Eastern bloc countries; by 2012 the share of students in Greek schools with immigrant background exceeded 10\%, having tripled over a decade. While in most countries immigrant students perform worse than natives in international assessments, there is considerable between-country heterogeneity. Using PISA 2012 for Mathematics and Reading achievement and a multilevel analysis, I find that Greece belongs to a small group of countries in which there is no evidence of an immigrant disadvantage for either first- or secondgeneration immigrants. The differences in achievement found in the raw data can be easily be accounted for by differences in socioeconomic background, school track, as well as differences in between-school quality.
\end{abstract}

Keywords: Educational achievement gap; immigrant students; multilevel analysis; Greece

\section{Introduction}

Since the late 1990s, following the regime change in the former Eastern Bloc countries, Spain, Italy, Greece, Portugal and Ireland (historically all emigration countries) became net receivers of immigration flows. As a result, the number of immigrant children in schools increased substantially. In 2012, the share of students in Greek schools with immigrant background exceeded $10 \%$ and this share had grown by 3.1 percentage points over the last decade (OECD, 2013).

In the great majority of countries, native students outperform immigrant students in international assessments (such as the Program for International Student Assessment (PISA)); however, there is large heterogeneity between countries. PISA 2012 data show that on average, immigrant students score 34 points lower ${ }^{1}$ than native students in the mathematics assessment. Even taking into account socioeconomic differences immigrant students score 21 points lower. Across all OECD countries, the performance gap narrowed by around 10 score points between 2003 and 2012.

The literature on the performance of immigrant students ${ }^{2}$ in international assessments draws attention to the finding that the lower performance of immigrant students compared to natives can be partly attributed to the fact that

\footnotetext{
* Associate Professor of Economics, Nanyang Technological University, Singapore.

${ }^{1}$ The average PISA score across countries is about 500 points.

${ }^{2}$ The literature on immigrant-native student performance differentials is summarized in section 3 .
} 
these students tend to be concentrated in disadvantaged schools; more specifically, findings from PISA indicate that it is primarily the concentration of disadvantage, not the concentration of immigrant students, that has detrimental effects on learning ${ }^{3}$. Across OECD countries, the concentration of immigrants in such "enclave schools" is particularly high in Greece, along with Canada and Italy. Another finding is that the country where immigrant students settle matters. Albanian students in Greece score 50 points higher in mathematics than Albanian students of similar socio-economic status in Montenegro, a difference that is very close to the average performance difference between students in Greece and students in Montenegro. Similarly, students from Arabic-speaking countries who settled in the Netherlands score 100 points higher in mathematics than students from the same countries who settled in Qatar, even after accounting for socio-economic differences (OECD, 2015).

In 2012, the native-immigrant mathematics gap in Greece, at 48 points (2 after accounting for socioeconomic differences), was significantly larger compared to the OECD average. Across OECD countries students in schools in which more than $25 \%$ of students are immigrants score 18 points lower on average (but only 5 points after accounting for differences in socioeconomic status). Among the countries with at least $10 \%$ of immigrant students in the school system, Greece exhibits the largest performance difference between the two groups even after accounting for socioeconomic status - 40 score points (OECD, 2013).

In this study, I investigate the educational achievement gap between 15year old immigrant schoolchildren and their native counterparts in Greece - a new immigration country, using PISA 2012 data. There is extensive literature on old immigration countries and some literature exists for other new immigration countries, such as Spain and Italy (for example, Azzolini, Schnell and Palmer, 2012); however, there is no dedicated country study for Greece. This study extends the literature by adopting a more appropriate methodology and specification.

I distinguish the achievement of immigrant students (relative to native students) by generational status - first generation and second generation; I also consider children of mixed-parentage as a separate category. The methodological approach is that of multilevel modelling; being the methodology of choice when analysing achievement data. Fixed coefficients are estimated for a variety of relevant cofactors, such as personal characteristics, socioeconomic and cultural background, grade placement of immigrant vs native students, language spoken at home, attitudes towards learning, school resources, as well as characteristics at the school level such as

\footnotetext{
3 Another finding is that in several countries (Bulgaria, Greece, Indonesia, Italy, Korea, Luxembourg, Mexico, the Slovak Republic and Sweden), native students with immigrant students in their class are less likely than students who have no immigrant student in their class to agree that immigrants have the same rights as other citizens; however, in the majority of other countries, the presence of immigrant students is associated with greater support for immigrants' rights (OECD, 2015).
} 
proportion of immigrant students and proportion of students from affluent households.

Section 2 discusses the developments with respect to immigration flows over the last decades and associated policies. Section 3 outlines the relevant literature, while section 4 discusses the data and methodology used. Section 5 presents and discusses the estimation results and section 6 concludes.

\section{Immigration and Policies: The Greek Context}

The pattern of immigration to Greece has often changed during the twentieth century. The main immigration boom was the result of the fall of the Soviet Union and transition of other former Eastern Bloc countries, when citizens of these countries who were of Greek heritage (co-ethnic Greeks) mainly from Albania and other Balkan nations, as well as economic migrants from the Balkans and Eastern European countries started coming into Greece in large numbers (Triandafyllidou, 2009). The large majority of immigrants to Greece come from Albania, followed by Bulgarians, Georgians, Romanians, Russians, and Ukrainians.

Until the mid-1990s, there was no formal legislative framework to manage immigration flows and immigration policy mainly relied on mass deportation of illegal (mainly Albanian) immigrants, with limited success. In the mid1990s, law 2416/96 was introduced to address intercultural education in Greece. By 1996, 26 intercultural schools, a special category of schools, had been established, along with reception classes for students with little or no knowledge of Greek (Paleologou, 2004; Triandafyllidou and Gropas, 2007). This number of intercultural schools is considered small by any standards, corresponding to only $0.17 \%$ of all schools.

Subsequently, article 40 of the 2910/2001 law stipulated that all children born to non-Greek nationals living in Greece have the right, irrespectively of legality or illegality of their parents, to compulsory education (Triandafyllidou and Gropas, 2007). Compulsory education in Greece for all children, native or foreign born, is from age 6 to age 15 .

The distribution of immigrant students in schools was uneven in the 90s and 00 s, with $36 \%$ of schools having no immigrant students; on the other hand, the greatest concentration of immigrant students was in the Athens area, where about $12 \%$ of the student population were immigrants (Hellenic Regional Development Centre, 2007). Furthermore, some of the intercultural schools were progressively becoming all-immigrant schools as Greek students, especially in the Athens area, were moving to other schools, such as private schools (Trouki and Panagopoulos 2006; Triandafyllidou and Gropas, 2007). In short, the separation in intercultural education combined with the insufficient number of intercultural schools was admittedly not a satisfactory state of affairs for the promotion of intercultural education. 


\section{Literature on Differences in Educational Outcomes and their Origins}

While immigrant students perform worse than natives in international assessments in most countries, there is considerable between-country heterogeneity in the extent and statistical significance of the difference and in rare cases immigrant students perform better than natives. This variance in findings points to a variety rather than a single explanation for immigrant students performing less well ${ }^{4}$.

The first explanation that comes to mind is that such differences are due to socioeconomic factors such as parents' education, job status and income. There is considerable empirical support for socioeconomic status as a significant determinant of immigrant-native achievement differentials (see for example, Driessen and Dekkers, 1997). A competing explanation is that of sociocultural differences (see for example Rumberger and Larson, 1998). Examples of such sociocultural factors are educational aspirations, parental pressure, drive and motivation. However, such sociocultural factors are expected to be important in explaining differences in educational performance between majority and certain minority populations (for example, students of Asian descent in the United States), rather than general performance differences between immigrant and non-immigrant student populations.

A third possible explanation is school related. If there is uneven distribution of immigrants in schools, i.e., concentration of immigrant students in some schools only, such schools may find it difficult to attract sufficient resources, such as good students. Similarly, immigrant students (especially first generation immigrants) are more likely to be placed in vocational programs or generally less academic programs. Hence, immigrant students will be more likely to exhibit lower educational attainment.

The empirical literature contains both international and single-country studies and most of them use PISA data. Marks (2005) investigated the contribution of socio-economic, sociocultural and school factors to the relative performance of first- and second-generation immigrant students in twenty countries using data from PISA 2000. He found that in most countries, the contribution of socio-economic factors for the weaker performance of immigrant students is substantial; on the other hand, sociocultural factors contribute little and school factors are not particularly important in most countries. Schnepf (2007) examined differences in educational achievement between immigrants and natives across ten OECD countries using PISA, TIMMS and PIRLS data. She finds an English-speaking vs. Continental European divide with language skills explaining the immigrant disadvantage in English speaking countries and socioeconomic background and school segregation being important in Continental countries.

Azzolini, Schnell and Palmer (2012) evaluated and compared the immigrant-native educational achievement gap in Spain and Italy - two "new immigration" countries. They found that accounting for socioeconomic

\footnotetext{
${ }^{4}$ Marks (2006) summarized the three main explanations before investigating the contribution of each on the immigrant - native achievement differential.
} 
background reduces the observed gaps to a very similar extent in the two countries, while language spoken at home is more strongly associated with achievement in Italy. They also found that school-type differentiation generally does not reduce immigrant-native gaps. Areepattamannil, Melkonian and Khine (2015) examined first- and second-generation immigrant adolescents' mathematics achievement in comparison to their native peers in Qatar. They find that both first- and second-generation immigrant students tended to have higher mathematics achievement, as wells as higher motivation to learn mathematics and lower anxiety towards mathematics than did their native counterparts.

The literature on Greece is thin, with one study which includes Greece. Schnell and Azzolini (2015) examined the academic achievement of immigrants in Italy, Spain, Greece and Portugal using data from PISA 2009 and 2012 in mathematics. The methodological approach is that of linear regression (instead of multilevel modelling - the most appropriate methodological approach). While this study controls for differences in socioeconomic status and basic characteristics, it does not control for attitudinal difference (sense of belonging, drive and motivation, parental pressure, etc.) and results which include school environment variables (such peer group characteristics) are not reported.

A few other studies focus on issues outside the scope of this study. Stefanidi et al. (2008) examined the association of immigrant status to adversity and adjustment using hierarchical regression and samples of first generation 12-15-year-old Albanian, Pontian (immigrants of Greek heritage) and native Greek students attending public schools. They found that in the Albanian schools, socioeconomic variables (SES) and life events were associated with worse adjustment and that immigrant status was associated with lower grades and fewer nominations as friends by classroom peers even after controlling for SES. In contrast, in the Pontian school, immigrant status was not of particular significance and only SES disadvantage was related to academic achievement as assessed by grades.

\section{Methodology and Data}

\section{Data and Descriptive Statistics}

PISA $2012^{5}$, like the previous PISA surveys, intends to measure what 15 year old students approaching the end of their compulsory schooling can do with what they learn at school. It emphasizes the mastery of processes, the understanding of concepts, and the ability to function in various types of situations.

\footnotetext{
${ }^{5}$ The development of PISA 2012-Mathematics was coordinated by an international consortium of educational research institutions contracted by the OECD, under the guidance of a group of mathematics experts from participating countries.
} 
The PISA 2012 contains information and simple indices on student, family background, school and teacher characteristics, as well as information on occupational status and educational level of parents, immigration and language background, measures of engagement with and at school, student drive and motivation, mathematics self-beliefs, disposition towards mathematics, disciplinary climate at school and teacher-student relations.

School level variables and indices contain information on school and class size, student-teacher ratio, school type, availability of computers, quality of teaching staff, ability grouping, use of assessments and school responsibility for curriculum and assessment. School level scale indices contain information on teacher shortages, quality of school resources and infrastructure, teacher and student behaviour and teacher morale.

The survey also contains the constructed index of Economic, Social and Cultural Status (ESCS), which is derived from three other indices: (a) highest occupational status of parent, (b) highest educational level of parents in years of education and (c) home possessions. The index of home possessions incorporates all items of the indices on household wealth (whether students lived in a household which had certain possessions, such as a room of their own certain items); household cultural possessions (such as books on literature, poetry, etc.); household educational resources (such as a desk, computer, etc.); and books at home. The ESCS index was derived using principal component analysis of standardized variables (OECD mean of zero and standard deviation of one), taking the factor scores of the first principal component as the measure of the ESCS index.

The proportion of missing values for important variables such as school type and index of Social Cultural and Economic status is small (generally under 3\%). Missing values were imputed using the method of relating observations in the original data to a set of fundamental variables with no or few missing values.

The sample is divided into four categories, considering generational status for immigrant students: (1) Natives (both parents native-born); (2) Firstgeneration immigrants (foreign born); (3) Second generation immigrants (both parents born abroad); and (4) Children of mixed-parentage. The decision to include a separate category for children of mixed-parentage was a marginal one, since, the latter, being predominantly native-born, are expected to be more similar to natives than immigrant students.

Two achievement scores were used (dependent variable): The Mathematics score and the Reading score. The scores used are the averages of the five plausible values in the survey. Table 1 presents the summary statistics by immigrant generational status. Immigrant students' mathematics score is substantially lower compared to natives and mixed-parentage students' score across the distribution of scores. The average mathematics score in the estimation sample is 457 points for natives, compared to 467 for mixedparentage students, 415 for second generation students and 404 for first generation students. Achievement score differences for Reading are substantially lower, with average scores of 483, 493, 468 and 425 respectively. 
Table 1. Summary Statistics - Immigrants vs. Natives

\begin{tabular}{|c|c|c|c|c|}
\hline Variable & Natives & $\begin{array}{c}1^{\text {st }} \\
\text { generation } \\
\text { Immigrants }\end{array}$ & $\begin{array}{c}2^{\text {nd }} \\
\text { generation } \\
\text { Immigrants }\end{array}$ & $\begin{array}{l}\text { Mixes } \\
\text { couples }\end{array}$ \\
\hline Mathematics Score & $\begin{array}{l}457.2 \\
(83.7)\end{array}$ & $\begin{array}{l}404.4 \\
(75.5)\end{array}$ & $\begin{array}{l}414.8 \\
(78.7)\end{array}$ & $\begin{array}{l}467.4 \\
(80.5)\end{array}$ \\
\hline Reading Score & $\begin{array}{l}483.2 \\
(91.2)\end{array}$ & $\begin{array}{l}424.6 \\
(95.7)\end{array}$ & $\begin{array}{l}468.4 \\
(76.6)\end{array}$ & $\begin{array}{l}493.3 \\
(89.6)\end{array}$ \\
\hline Age & $\begin{array}{l}15.72 \\
(0.28)\end{array}$ & $\begin{array}{l}15.72 \\
(0.29)\end{array}$ & $\begin{array}{l}15.71 \\
(0.28)\end{array}$ & $\begin{array}{l}15.72 \\
(0.28)\end{array}$ \\
\hline Male (\%) & $\begin{array}{c}0.501 \\
(0.500)\end{array}$ & $\begin{array}{c}0.501 \\
(0.501)\end{array}$ & $\begin{array}{c}0.489 \\
(0.501)\end{array}$ & $\begin{array}{l}0.436 \\
(0.50)\end{array}$ \\
\hline Two parent family (\%) & $\begin{array}{l}0.908 \\
(0.29)\end{array}$ & $\begin{array}{l}0.909 \\
(0.29)\end{array}$ & $\begin{array}{l}0.919 \\
(0.27)\end{array}$ & $\begin{array}{l}0.909 \\
(0.29)\end{array}$ \\
\hline Attica region (\%) & $\begin{array}{l}0.315 \\
(0.46)\end{array}$ & $\begin{array}{l}0.364 \\
(0.48)\end{array}$ & $\begin{array}{l}0.427 \\
(0.50)\end{array}$ & $\begin{array}{l}0.316 \\
(0.46)\end{array}$ \\
\hline $\begin{array}{l}\text { Language at home: not Greek } \\
(\%)\end{array}$ & $\begin{array}{c}0.009 \\
(0.094)\end{array}$ & $\begin{array}{l}0.568 \\
(0.50)\end{array}$ & $\begin{array}{l}0.157 \\
(0.36)\end{array}$ & $\begin{array}{c}0.053 \\
(0.022)\end{array}$ \\
\hline & 0.131 & 0.181 & 0.132 & $\begin{array}{l}0.143 \\
(0.35)\end{array}$ \\
\hline Program vocational (\%) & $\begin{array}{c}(0.034) \\
0.026\end{array}$ & $\begin{array}{c}(0.39) \\
0.400\end{array}$ & $\begin{array}{l}(0.34) \\
0.200\end{array}$ & $\begin{array}{l}(0.35) \\
0.008\end{array}$ \\
\hline $\begin{array}{l}\text { Lower secondary (ISED2) } \\
(\%)\end{array}$ & $\begin{array}{c}(0.016) \\
12.38 \\
(8.92)\end{array}$ & $\begin{array}{l}(0.49) \\
10.70 \\
(8.32)\end{array}$ & $\begin{array}{l}(0.40) \\
10.66 \\
(8.73)\end{array}$ & $\begin{array}{l}(0.09) \\
12.09 \\
(9.19)\end{array}$ \\
\hline Out of school study time & $\begin{array}{l}0.216 \\
(0.41)\end{array}$ & $\begin{array}{l}0.139 \\
(0.35)\end{array}$ & $\begin{array}{l}0.136 \\
(0.34)\end{array}$ & $\begin{array}{l}0.184 \\
(0.39)\end{array}$ \\
\hline Strong parental pressure & $\begin{array}{l}-0.032 \\
(0.82)\end{array}$ & $\begin{array}{l}-0.079 \\
(0.86)\end{array}$ & $\begin{array}{l}-0.080 \\
(0.83)\end{array}$ & $\begin{array}{l}-0.033 \\
(0.83)\end{array}$ \\
\hline Perseverance index & $\begin{array}{l}-0.123 \\
(0.88)\end{array}$ & $\begin{array}{l}-0.279 \\
(0.91)\end{array}$ & $\begin{array}{l}-0.097 \\
(0.74)\end{array}$ & $\begin{array}{l}-0.122 \\
(0.77)\end{array}$ \\
\hline Sense of belonging index & $\begin{array}{l}0.020 \\
(0.88)\end{array}$ & $\begin{array}{l}0.089 \\
(0.80)\end{array}$ & $\begin{array}{l}-0.072 \\
(0.89)\end{array}$ & $\begin{array}{l}0.080 \\
(0.89)\end{array}$ \\
\hline Dive and motivation index & $\begin{array}{l}-0.010 \\
(0.99)\end{array}$ & $\begin{array}{l}-0.826 \\
(0.80)\end{array}$ & $\begin{array}{l}-0.464 \\
(0.91)\end{array}$ & $\begin{array}{l}0.163 \\
(0.87)\end{array}$ \\
\hline ESCS index & $\begin{array}{c}321.6 \\
(216.1)\end{array}$ & $\begin{array}{c}282.3 \\
(191.8)\end{array}$ & $\begin{array}{c}286.0 \\
(196.2)\end{array}$ & $\begin{array}{l}329.1 \\
(208.9)\end{array}$ \\
\hline School size & $\begin{array}{l}0.032 \\
(1.06)\end{array}$ & $\begin{array}{l}0.023 \\
(0.93)\end{array}$ & $\begin{array}{l}0.119 \\
(1.08)\end{array}$ & $\begin{array}{l}-0.050 \\
(1.06)\end{array}$ \\
\hline Student climate index & $\begin{array}{l}-0.404 \\
(0.96)\end{array}$ & $\begin{array}{l}-0.411 \\
(0.87)\end{array}$ & $\begin{array}{l}-0.445 \\
(0.79)\end{array}$ & $\begin{array}{l}-0.486 \\
(0.86)\end{array}$ \\
\hline Teacher shortage index & $\begin{array}{l}-0.034 \\
(0.54)\end{array}$ & $\begin{array}{l}-0.496 \\
(0.56)\end{array}$ & $\begin{array}{l}-0.209 \\
(0.499)\end{array}$ & $\begin{array}{l}0.007 \\
(0.54)\end{array}$ \\
\hline ESCS index at school level & $\begin{array}{c}8.34 \\
(9.14)\end{array}$ & $\begin{array}{c}27.1 \\
(22.2)\end{array}$ & $\begin{array}{c}21.1 \\
(17.2)\end{array}$ & $\begin{array}{l}8.50 \\
(9.4)\end{array}$ \\
\hline $\begin{array}{l}\text { \% immigrant students } \\
\text { (school) }\end{array}$ & & & & \\
\hline $\mathrm{N}$ & 4,234 & 279 & 207 & 405 \\
\hline
\end{tabular}


Besides the self-explanatory characteristics listed in Table 1, such as age, gender, family composition, location and language spoken at home (same or other than the test language), there is a series of indices (for perseverance, sense of belonging, drive and motivation, student climate, teacher shortage) which take a continuum of negative and positive values ${ }^{6}$. Two variables refer to program track and grade, namely Program Vocational (instead of Academic track) and Lower Secondary (15-year-olds who have not made yet the transition to Upper Secondary education). The variable "Strong Parental Pressure" is derived from the question to schools on the frequency of parental achievement pressure (taking the value of 1 if the response is "many parents" and 0 if the response is "minority of parents" or "largely absent"). Finally, two new variables at the school level were generated: "ESCS index at school level" (peer group quality at the school level) and "\% immigrant students" (measuring the concentration of immigrant students in a student's school).

Testing pairwise differences for average scores, as well as for different characteristics reveals many statistically significant differences (at the $5 \%$ level or lower) between groups. Native students score higher in mathematics compared to $1^{\text {st }}$ and $2^{\text {nd }}$ generation immigrants, while mixed parentage students score higher than native students. With respect to Reading performance, all pairwise differences in performance are significant, except those between natives and mixed-parentage students.

Statistically significant differences in Social Economic and Cultural status are found between all pairwise differences, without exception. Of interest is the significant difference (at the 1\% level) between natives and students of mixedparentage in favour of students of mixed parentage. Further, investigation using the information on parents' education suggests that immigrants who marry Greek citizens tend to be more educated, and tend to marry more educated Greek citizens.

Differences in speaking a language other than Greek at home are significant in all pairwise comparisons. Differences in concentration of students in the Aticca region are significant between natives on the one hand and $1^{\text {st }}$ and $2^{\text {nd }}$ generation immigrants on the other, as well as between natives and mixed-parentage students. Differences in vocational (rather than academic) orientation programs are observed between natives and $1^{\text {st }}$ generation immigrants, between $1^{\text {st }}$ and $2^{\text {nd }}$ generation immigrants, as well as between $1^{\text {st }}$ generation immigrants and students of mixed-parentage. Out-of-school study time is different only between natives and $1^{\text {st }}$ and $2^{\text {nd }}$ generation immigrants. This is also the case for differences in parental pressure. Sense of belonging differs only between $1^{\text {st }}$ generation immigrants and natives, with $1^{\text {st }}$ generation immigrants associated with lower sense of belonging. The quality of schoolpeer groups differs in all pairwise comparisons, except between natives and mixed-parentage students. This is also the case for the concentration of immigrant students in schools.

\footnotetext{
${ }^{6}$ Negative values for an index do not necessarily imply that students responded negatively; it merely indicates that the respondents answered less positively than all respondents.
} 
Finally, no significant differences were detected in other individual, family and school characteristics; such as age, gender, two vs. one parent families, perseverance, drive and motivation, school size, student climate in school, and shortage of teachers.

\section{Methodology}

I use multilevel analysis, the preferred methodology in handling the nested structure of PISA data, by estimating a mixed-effects model. Student achievement scores are associated to immigrant generational status and a variety of other student, family, attitudinal and school environment characteristics. A mixed effects model has both random and fixed effects as opposed to a standard linear regression model which has only fixed effects. Using multilevel modelling one can distinguish within school level variation associated with various school level (observed) characteristics (such as sector, school resources location, etc.), from residual (unobserved) between-school variation. The second can be seen as being associated to differences in school quality (Hanushek and Rivkin, 2010; Snijders and Bosker, 1999).

When students are clustered in groups (such as schools), randomly selected students in the same school are expected to be more similar compared to students in another school; consequently, we expect test scores to be more similar than scores in a different school, since they share features of the particular school such as teacher characteristics and student demographics. One needs, therefore, to take into account clustering; otherwise the standard errors of regression coefficients will be underestimated.

The model which takes into account the hierarchical structure of the data and the estimation of random intercepts associated with a student $i$ belonging to school $j$ is:

$$
\operatorname{SCORE}_{i j}=X_{i j} \beta+S_{j} \gamma+u_{j}+\varepsilon_{i j}
$$

where $\mathrm{X}_{\mathrm{ij}}$ are the individual and family characteristics of student $\mathrm{i}$ in school $\mathrm{j}$ identified in the literature as relevant determinants of school performance and $\mathrm{Sj}$ are the characteristics (resources) of school $\mathrm{j}$ shared by all students attending school $j$, as well as average characteristics at the school level (such as quality of peer groups and proportion of immigrant students). The random component $\mathrm{u}_{\mathrm{j}}$ is an estimate of the systematic effect of school $\mathrm{j}$ on scores, over and above the effect of the observed school related covariates $(\mathrm{S} j)$ and $\varepsilon_{\mathrm{ij}}$ is a student level residual.

One reason for using multilevel modelling with random effects is to obtain correct standard errors. An additional reason is to estimate and assess the remaining (residual) between school variation after accounting for observed school level characteristics. If ordinary least-squares was used, the correlation between the student level error terms would be ignored and thus the estimates 
of the parameters would be biased ${ }^{7}$; this is because one would be treating all students in the country as one group ignoring the fact that a student attends a specific school which could be a low or high quality school.

\section{Results}

\section{Model Estimation}

Two outcome measures were used: mathematics literacy and reading literacy. The dependent variables are the average of the five plausible values in PISA. Hierarchical linear modelling was implemented with the estimation of a mixed-effects model with random intercepts; sampling weights for both students and schools were used and the estimation method is that of maximum likelihood estimation (MLE). The estimation sample consists of 4,715 observations with 159 groups (schools).

The predictor variables include dichotomous as well as continuous variables and some of the continuous variables are indices. All index controls have been standardized (mean 0 and standard deviation of 1), to facilitate interpretation of estimated coefficients (effect of an increase in the relevant index by one standard deviation). The set of predictors consists of the three immigrant status dummies; student demographic variables (age ${ }^{8}$, gender, single-parent family, area of residence); whether language spoken at home is the language of the test (indicator for language spoken at home being other than Greek); school track (indicator for following vocational tracks instead of academic) and the grade level a student is placed (lower secondary academic grade, compared to the academic grade consistent with their age); socioeconomic status of student's family (Economic, Social and Cultural Status index - ESCS index); sense of belonging and attitudes towards learning (sense of belonging index, index of perseverance, drive and motivation index, a strong parental pressure dummy and hours of out of school study time per week); school characteristics (school size, index of student disciplinary climate, and shortage of teachers) and; finally, average school characteristics (school average of ESCS index and percent of immigrant students).

Controlling for school track and grade is important for estimating the immigrant-native achievement gap, since the PISA surveys contain information for students who are approximately age 15 and not students in a particular grade, who could be of any age. Similar to immigrants in the majority of countries, immigrant students in Greece are over-represented in vocational tracks and lower grade levels. Not controlling for track and grade could create the impression that immigrant students are disadvantaged as they compete against students in higher grades. Grade retention associated with academic

\footnotetext{
7 If the data available were aggregated at the school level, then one could estimate the parameters using Ordinary Least Squares.

${ }^{8}$ Although PISA participants' average age is 15.7 years, age in the sample used in the current study varies between 15.2 and 16.2 years.
} 
failure is not the only possible reason for immigrant students being overrepresented in lower grades; some parents of immigrant students could be deliberately enrolling their children in a lower grade to increase the chance of successfully competing with native students and mature academically before entering a higher grade (known as "redshirting"; see also Pong, 2009).

\section{Results}

Tables $2 \mathrm{a}$ and $2 \mathrm{~b}$ contain the estimation results for mathematics and reading achievement respectively. The first panel presents the fixed coefficients, while the second panel summarizes the random effects through the estimated variance of random intercepts, the (residual) student variance and the intra-school correlation. The intra-school correlation reflects the remaining between-school variation after accounting for observed school level variation (variation in average achievement scores in different schools).

odel 1 includes only the three immigrant status dummies, after allowing for random intercepts. In mathematics, the negative first and second generation immigrant coefficients (-16 and -18 PISA points respectively), while being statistically significant, are quite small in size compared to the raw differences (-53 and -42 points respectively). On the contrary, children of mixed-parentage appear to perform better; namely, by 12 points, compared to a 10-point raw score difference. In reading, the negative effect of first generation immigrants (-22 points compared to a -59-point raw score difference) is accompanied by a statistically insignificant effect for second generation immigrants (compared to a -15-point raw score difference) and a positive and significant effect for children of mixed-parentage. In other words, accounting for random school intercepts, eliminates the raw score differential between second generation immigrants and natives. We notice than in this model, 39\% (mathematics) and $51 \%$ (reading) of the total variance in scores are due to between-school differences. 
Table 2a. Weighted Multilevel Models of Mathematics Literacy

\section{Variable \\ $1^{\text {st }}$ generation immigrant \\ $2^{\text {nd }}$ generation immigrant}

Mixed-parentage

Age

Male

Athens

One-parent family

Language at home: other

Vocational program

Lower secondary

ESCS index

Out of school study time (h/week)

Strong parental pressure

Perseverance index (stad.)

Sense of belonging index (stad.)

\begin{tabular}{|c|c|c|c|c|c|}
\hline Model 1 & Model 2 & Model 3 & Model 4 & Model 5 & Model 6 \\
\hline$-15.6^{*}$ & -6.09 & 4.72 & 3.13 & 3.26 & 1.77 \\
\hline$(5.1)$ & $(6.4)$ & (6.2) & (5.8) & (5.8) & $(5.8)$ \\
\hline$-18.3^{*}$ & -10.1 & -4.18 & -4.07 & -3.92 & -5.21 \\
\hline$(6.2)$ & (10.0) & (9.5) & $(8.7)$ & $(8.8)$ & $(8.6)$ \\
\hline $11.6^{*}$ & $12.9 *$ & $10.2 *$ & $9.12 *$ & $9.18 *$ & $8.86^{*}$ \\
\hline$(3.6)$ & (3.7) & $(3.6)$ & $(3.5)$ & $(3.6)$ & $(3.5)$ \\
\hline \multirow[t]{2}{*}{-} & 6.79 & $7.2^{*}$ & 6.36 & 6.20 & 6.42 \\
\hline & (3.7) & (3.6) & (3.8) & (3.8) & (3.8) \\
\hline \multirow[t]{2}{*}{-} & $21.6 *$ & $19.9 *$ & $18.5 *$ & $18.5^{*}$ & $18.4^{*}$ \\
\hline & $(2.5)$ & $(2.4)$ & $(2.3)$ & $(2.3)$ & $(2.3)$ \\
\hline \multirow[t]{2}{*}{-} & $14.8 *$ & 6.78 & 6.54 & 4.12 & -10.9 \\
\hline & $(6.9)$ & (6.0) & (6.2) & (6.1) & (5.9) \\
\hline \multirow[t]{2}{*}{-} & -3.43 & -2.15 & -1.91 & -2.08 & -2.27 \\
\hline & (4.0) & $(3.9)$ & $(3.7)$ & $(3.7)$ & $(3.7)$ \\
\hline \multirow[t]{2}{*}{-} & -11.9 & $-14.3 *$ & $-14.5^{*}$ & $-14.7 *$ & $-14.6^{*}$ \\
\hline & $(8.0)$ & $(7.2)$ & $(7.1)$ & $(7.1)$ & $(7.2)$ \\
\hline \multirow[t]{2}{*}{ - } & $-91.5^{*}$ & $-83.8^{*}$ & $-75.9^{*}$ & $-75.7 *$ & $-65.1 *$ \\
\hline & $(8.5)$ & $(7.9)$ & $(8.1)$ & $(7.3)$ & $(8.3)$ \\
\hline \multirow[t]{2}{*}{ - } & $-111.4^{*}$ & $-102.4 *$ & $-96.6^{*}$ & $-93.0 *$ & $-92.1 *$ \\
\hline & (10.4) & $(9.1)$ & $(9.8)$ & $(9.2)$ & (18.3) \\
\hline \multirow[t]{2}{*}{-} & - & $17.5^{*}$ & $15.1^{*}$ & $14.9 *$ & $13.5^{*}$ \\
\hline & & (1.6) & $(1.5)$ & $(1.5)$ & $(1.5)$ \\
\hline \multirow[t]{2}{*}{-} & - & - & 0.10 & 0.10 & 0.09 \\
\hline & & & $(0.13)$ & (0.13) & $(0.13)$ \\
\hline \multirow[t]{2}{*}{ - } & - & - & 13.0 & $16.5^{*}$ & 10.8 \\
\hline & & & $(7.9)$ & $(7.8)$ & $(7.9)$ \\
\hline \multirow[t]{2}{*}{-} & - & - & $8.90 *$ & $8.91 *$ & $8.86^{*}$ \\
\hline & & & $(1.2)$ & $(1.2)$ & $(1.2)$ \\
\hline \multirow[t]{2}{*}{-} & - & - & $4.99 *$ & $5.00 *$ & $5.05^{*}$ \\
\hline & & & $(1.1)$ & $(1.1)$ & (1.1) \\
\hline
\end{tabular}


Drive and motivation index (stad.)

\section{School size}

Student disciplinary climate index (stad.)

Shortage of teachers index (stad.)

ESC index at school level (stad.)

$\%$ if immigrant students at school

\section{Constant}

1. School variance (constants)

2. Student variance (residual)

Intra-school correlation: $1 /(1+2)$

Log-likelihood

$\mathrm{N}$

Number of groups (schools)

$\begin{array}{ll}- & - \\ - & - \\ - & - \\ - & - \\ - & - \\ - & -\end{array}$

436.3

(5.2)

2,838

(342.5)

4,470

(124.3)

$38.8 \%$

$-244,907$

4,911

159

\section{3}

(58.7)

1,057

(192.2)

4,340

(113.5)

$19.6 \%$

$-232,661$

4,715

-
-
-
-
-
-
-

$9.36^{*}$

(1.0)

-$$
-
$$$$
-
$$$$
-
$$

$-$

336.9

(57.3)

735.0

(146.5)

4,163

(108.7)

$15.0 \%$

$-231,600$

4,715

159

4,715
159
9.57*

(1.0)

0.02 *

(0.01)

$-1.19$

(3.1)

$-1.45$

(2.5)

$17.5 *$

(2.9)

0.36

(0.27)

343.8

(60.1)

$(60.1)$
466.5

$(112.8)$

3,893

(96.5)

$\begin{array}{lll}3,894 & 3,893 & 3,893 \\ (97.3) & (97.1) & (96.5)\end{array}$

$\begin{array}{lll}16.0 \% & 14.4 \% & 10.6 \%\end{array}$

$-230,270$

$-230,186$

$-229,980$

159

159 
Table 2b. Weighted Multilevel Models of Reading Literacy

\begin{tabular}{|c|c|c|c|c|c|c|}
\hline Variable & $\begin{array}{c}\text { Model } \\
1\end{array}$ & $\begin{array}{c}\text { Model } \\
2\end{array}$ & $\begin{array}{c}\text { Model } \\
3\end{array}$ & $\begin{array}{c}\text { Model } \\
4\end{array}$ & $\begin{array}{c}\text { Model } \\
5\end{array}$ & $\begin{array}{c}\text { Model } \\
6\end{array}$ \\
\hline $1^{\text {st }}$ generation immigrant & $\begin{array}{c}-21.6^{*} \\
(5.4)\end{array}$ & $\begin{array}{r}-7.49 \\
(7.0)\end{array}$ & $\begin{array}{l}1.37 \\
(6.9)\end{array}$ & $\begin{array}{l}0.69 \\
(6.4)\end{array}$ & $\begin{array}{l}0.97 \\
(6.5)\end{array}$ & $\begin{array}{r}-1.43 \\
(6.6)\end{array}$ \\
\hline $2^{\text {nd }}$ generation immigrant & $\begin{array}{l}0.74 \\
(8.7)\end{array}$ & $\begin{array}{c}6.61 \\
(10.6)\end{array}$ & $\begin{array}{c}11.4 \\
(10.1)\end{array}$ & $\begin{array}{l}10.6 \\
(9.5)\end{array}$ & $\begin{array}{l}10.9 \\
(9.6)\end{array}$ & $\begin{array}{l}8.29 \\
(9.4)\end{array}$ \\
\hline Mixed-parentage & $\begin{array}{l}10.6^{*} \\
(3.6)\end{array}$ & $\begin{array}{l}8.59 * \\
(3.4)\end{array}$ & $\begin{array}{l}6.45 \\
(3.5)\end{array}$ & $\begin{array}{l}6.19 \\
(3.5)\end{array}$ & $\begin{array}{l}6.26 \\
(3.5)\end{array}$ & $\begin{array}{l}5.60 \\
(3.5)\end{array}$ \\
\hline Age & - & $\begin{array}{l}5.56 \\
(4.4)\end{array}$ & $\begin{array}{l}5.76 \\
(4.4)\end{array}$ & $\begin{array}{l}5.45 \\
(4.5)\end{array}$ & $\begin{array}{l}5.15 \\
(4.5)\end{array}$ & $\begin{array}{l}5.31 \\
(4.6)\end{array}$ \\
\hline Male & - & $\begin{array}{c}-34.6^{*} \\
(3.9)\end{array}$ & $\begin{array}{c}-35.9 * \\
(2.9)\end{array}$ & $\begin{array}{c}-35.3 * \\
(2.7)\end{array}$ & $\begin{array}{c}-35.3^{*} \\
(2.7)\end{array}$ & $\begin{array}{c}-35.5^{*} \\
(2.7)\end{array}$ \\
\hline Athens & - & $\begin{array}{c}21.4^{*} \\
(9.0)\end{array}$ & $\begin{array}{l}14.8 \\
(8.4)\end{array}$ & $\begin{array}{l}14.5 \\
(8.5)\end{array}$ & $\begin{array}{l}10.5 \\
(9.1)\end{array}$ & $\begin{array}{l}-11.8 \\
(8.7)\end{array}$ \\
\hline One-parent family & - & $\begin{array}{c}-10.6^{*} \\
(4.1)\end{array}$ & $\begin{array}{c}-9.63^{*} \\
(4.1)\end{array}$ & $\begin{array}{c}-9.13^{*} \\
(3.9)\end{array}$ & $\begin{array}{c}-9.39 * \\
(3.9)\end{array}$ & $\begin{array}{c}-9.46^{*} \\
(3.8)\end{array}$ \\
\hline Language at home: other & - & $\begin{array}{c}-21.8^{*} \\
(8.8)\end{array}$ & $\begin{array}{c}-23.5^{*} \\
(8.2)\end{array}$ & $\begin{array}{c}-23.4^{*} \\
(8.0)\end{array}$ & $\begin{array}{c}-23.4^{*} \\
(8.0)\end{array}$ & $\begin{array}{c}-24.1^{*} \\
(8.2)\end{array}$ \\
\hline Vocational program & - & $\begin{array}{c}-109.7 * \\
(11.0)\end{array}$ & $\begin{array}{c}-103.5^{*} \\
(10.6)\end{array}$ & $\begin{array}{l}-97.1^{*} \\
(10.7)\end{array}$ & $\begin{array}{c}-98.2^{*} \\
(9.9)\end{array}$ & $\begin{array}{l}-90.3^{*} \\
(10.9)\end{array}$ \\
\hline Lower secondary & - & $\begin{array}{c}-146.4^{*} \\
(20.0)\end{array}$ & $\begin{array}{c}-138.5 * \\
(19.5)\end{array}$ & $\begin{array}{c}-131.6^{*} \\
(19.6)\end{array}$ & $\begin{array}{c}-127.3 * \\
(19.2)\end{array}$ & $\begin{array}{c}-160.1^{*} \\
(18.9)\end{array}$ \\
\hline ESCS index & - & - & $\begin{array}{l}14.1 * \\
(1.7)\end{array}$ & $\begin{array}{l}12.3^{*} \\
(1.6)\end{array}$ & $\begin{array}{l}12.1^{*} \\
(1.6)\end{array}$ & $\begin{array}{l}10.8^{*} \\
(1.6)\end{array}$ \\
\hline Out of school study time (h/week) & - & - & - & $\begin{array}{l}0.26^{*} \\
(0.13)\end{array}$ & $\begin{array}{l}0.26^{*} \\
(0.13)\end{array}$ & $\begin{array}{c}0.25 \\
(0.13)\end{array}$ \\
\hline Strong parental pressure & - & - & - & $\begin{array}{l}7.94 \\
(7.7)\end{array}$ & $\begin{array}{l}14.5 \\
(8.2)\end{array}$ & $\begin{array}{l}11.4 \\
(7.9)\end{array}$ \\
\hline Perseverance index (stad.) & - & - & - & $\begin{array}{l}5.79^{*} \\
(1.1)\end{array}$ & $\begin{array}{c}5.79 * \\
(1.1)\end{array}$ & $\begin{array}{l}5.79 \\
(1.1)\end{array}$ \\
\hline Sense of belonging index (stad.) & - & - & - & $\begin{array}{l}7.34 * \\
(1.1)\end{array}$ & $\begin{array}{l}7.38^{*} \\
(1.1)\end{array}$ & $\begin{array}{l}7.49 * \\
(1.1)\end{array}$ \\
\hline Drive and motivation index (stad.) & - & - & - & $\begin{array}{c}2.56^{*} \\
(1.1)\end{array}$ & $\begin{array}{c}2.61 * \\
(1.1)\end{array}$ & $\begin{array}{c}2.77 * \\
(1.1)\end{array}$ \\
\hline School size & - & - & - & - & $\begin{array}{l}0.060^{*} \\
(0.16)\end{array}$ & $\begin{array}{l}0.032 * \\
(0.01)\end{array}$ \\
\hline $\begin{array}{l}\text { Student disciplinary climate index } \\
\text { (stad.) }\end{array}$ & - & - & - & - & $\begin{array}{c}-1.16 \\
(3.6)\end{array}$ & $\begin{array}{l}-5.85 \\
(3.3)\end{array}$ \\
\hline Shortage of teachers index (stad.) & - & - & - & - & $\begin{array}{c}5.17 \\
(10.0)\end{array}$ & $\begin{array}{l}12.3 \\
(9.4) \\
19.9 *\end{array}$ \\
\hline ESCS index at school level (stad.) & - & - & - & - & - & $1.09 *$ \\
\hline$\%$ if immigrant students at school & $\begin{array}{l}453.1 \\
(7.1)\end{array}$ & $\begin{array}{l}402.1 \\
(68.5)\end{array}$ & $\begin{array}{l}403.0 \\
(68.8)\end{array}$ & $\begin{array}{l}402.0 \\
(70.7)\end{array}$ & $\begin{array}{l}390.5 \\
(70.6)\end{array}$ & $\begin{array}{l}(0.28) \\
398.0 \\
(71.8)\end{array}$ \\
\hline 1. School variance (constants) & $\begin{array}{l}5,180 \\
(982.7)\end{array}$ & $\begin{array}{c}1,442 \\
(302.3)\end{array}$ & $\begin{array}{c}1,145 \\
(279.6)\end{array}$ & $\begin{array}{c}1,143 \\
(282.6)\end{array}$ & $\begin{array}{l}994.5 \\
(256.7)\end{array}$ & $\begin{array}{c}662.2 \\
(211.4)\end{array}$ \\
\hline 2. Student variance (residual) & $\begin{array}{c}4,908 \\
(165.9)\end{array}$ & $\begin{array}{c}4,537 \\
(145.4)\end{array}$ & $\begin{array}{c}4,426 \\
(152.4)\end{array}$ & $\begin{array}{c}4,307 \\
(147.0)\end{array}$ & $\begin{array}{c}4,306 \\
(146.7)\end{array}$ & $\begin{array}{c}4,307 \\
(145.2)\end{array}$ \\
\hline Intra-school correlation: $1 /(1+2)$ & $51.3 \%$ & $24.1 \%$ & $20.5 \%$ & $20.94 \%$ & $18.8 \%$ & $13.3 \%$ \\
\hline Log-likelihood & $-247,294$ & $-233,752$ & $-233,104$ & $-232,559$ & $\begin{array}{c}- \\
232,468\end{array}$ & $\begin{array}{c}- \\
232,196\end{array}$ \\
\hline $\begin{array}{l}\mathrm{N} \\
\text { Number of groups (schools) }\end{array}$ & $\begin{array}{c}4,911 \\
159\end{array}$ & $\begin{array}{c}4,715 \\
159\end{array}$ & $\begin{array}{c}4,715 \\
159\end{array}$ & $\begin{array}{c}4,715 \\
159\end{array}$ & $\begin{array}{c}4,715 \\
159\end{array}$ & $\begin{array}{c}4,715 \\
159\end{array}$ \\
\hline
\end{tabular}

Note: standard errors in parentheses; * indicates significance at the $5 \%$ level or lower. 
Model 2 controls for personal and demographic characteristics, including language spoken at home and school track or grade. One notices the much lower average achievement scores of students in vocational track and lower grades for both mathematics and reading. Speaking at home a language other than the language of the test is detrimental mainly to reading achievement and less so to mathematics achievement. The gender coefficient is consistent with what is already known in the literature, i.e., boys outperform girls in mathematics, while girls outperform boys in reading in the great majority of countries. Having controlled for demographic characteristics, language spoken at home and school track and grade, there are no significant differences in achievement between immigrant and native students; however, mixedparentage students still perform better than native students. Total variance declined by $26 \%$ for mathematics and $43 \%$ for reading, with between-school variance declining by $63 \%$ and $72 \%$ respectively. Accounting for differences in family Social, Economic and Cultural status (Model 3) further narrows the already insignificant immigrant-native gaps, while a moderate advantage remains for mixed-parentage students, but only in mathematics. Model 4, which controls for attitudinal attributes does not appreciably decrease variances, while Model 5 which controls for school characteristics results in a small decrease in between-school variance with immigrant status coefficients remaining approximately unchanged.

The full model (Model 6) controls for average ESC status at school (concentration of disadvantage) and proportion of first or second generation immigrant students at school. The quality of peer groups is an important determinant of achievement; one standard deviation increase in ESC status is associated with 18 (20) point increase in achievement score in mathematics (reading). On the other hand, an increase in the proportion of immigrant students in the school does not affect the mathematics score, while the statistically significant effect from one percentage point increase in the proportion of immigrant students on the reading score is only one PISA point. The implication is that it is mainly the concentration of disadvantage in schools which affects achievement of students, instead of the concentration of immigrant students. The additional controls in Model 6 further reduce the between school variance by $29 \%$ for mathematics and $33 \%$ for reading. The remaining between-school variance (which can be interpreted as representing unaccounted differences in school quality) is about $10.5 \%$ of the total variance in mathematics and $13 \%$ of the total variance in reading.

I also derived results using a restricted sample, by removing observations for students attending vocational schools and students who are in a lower than their age-appropriate grade. I found that after controlling for ESC status, the first and second generation immigrant effects disappear, resulting in the same conclusion, i.e., that there is no evidence of an immigrant achievement disadvantage.

Comparing the results to other studies on "new immigrant" countries (Italy, Spain, Greece and Portugal), shows that the results of this study on Greece differ from those for Italy and Spain. Azzolini, Schnell and Palmer 
(2012) found that in Italy and Spain, significant achievement gaps between natives and children of immigrants remain even after controlling for family and school characteristics. They also found that second-generation students perform better than first-generation students. Schnell and Azzolini (2015), who included Greece in their study, showed that there is a similar, significant immigrant disadvantage in Italy and Spain for both first- and second-generation immigrants. In Portugal, second generation immigrants are the only ones who face such disadvantage while in the case of Greece no disadvantage was observed.

Concluding, the international empirical literature finds that in most countries the educational performance of immigrants is substantially lower than that of natives, even after accounting for differences in socioeconomic and other characteristics. However, there is some heterogeneity within a minority of countries, such as Australia, Canada and New Zealand, which apply selective immigration policies. These countries exhibit either no significant differences or even an advantage for immigrant over native students. ${ }^{9}$ This study finds that Greece, which does not practice selective immigration policies, belongs to this small group of countries, in which there is no evidence of an immigrant disadvantage. The differences in achievement found in the raw data can be easily accounted for by differences in socioeconomic background, school track and grade, as well as differences in between-school quality.

The findings of this study are relevant in the current context, in the light of the recent refugee crisis. Given the current EU policy which discourages the movement of refugees to Northern European countries and the shaky nature of the refugee agreement with Turkey, large numbers of refugees may remain in Greece. Their children will have to attend compulsory education in Greek schools. Hence, the findings could have useful policy implications for the education of Syrian and other students in Greece.

\section{Summary}

Greece, a new immigration country, experienced an immigration boom starting in the 1970s and reached its peak in the 1980s. In 2012, Albanian migrants constituted $55-60 \%$ or more of the immigrant population, while immigrants from the ex-Soviet Union and other Eastern bloc countries, (including immigrants of Greek heritage, were represented in significant proportions. As a result, the number of immigrant children in schools increased substantially and by 2012, the share of students in Greek schools with immigrant background exceeded $10 \%$, having tripled over a decade. The distribution of immigrant students in schools is uneven with $36 \%$ of schools having no immigrant students, while the greatest concentration of immigrant students is in the Athens area.

\footnotetext{
${ }^{9}$ There is some empirical evidence that this is the case for Australia and Singapore (Akther and Robinson, 2014).
} 
While in most countries immigrant students perform worse than natives in international assessments, there is considerable between-country heterogeneity, with immigrants performing equally well or even better in some countries (mostly in countries using selective immigration policies), even after accounting for a variety of characteristics.

I use PISA 2012 for mathematics and reading achievement, employing a multilevel regression methodology which can distinguish school level variation associated with various school level (observed) characteristics (such as sector, school resources location, etc.), from residual (unobserved) between-school variation. After accounting for demographic characteristics, school track, socioeconomic background, school characteristics and peer group effects, I find that Greece, which does not practice selective immigration policies, belongs to this small group of countries in which there is no evidence of an immigrant disadvantage. The differences in achievement found in the raw data can be easily be accounted for by differences in socioeconomic background, school track and grade, as well as differences in between-school quality.

\section{References}

Azzolini D, Schnell P and Palmer J (2012) Educational achievement gaps between immigrant and native students in two "new immigration" countries: Italy and Spain in comparison. Annals of the American Academy of Political and Social Science, 643 (1): 46-77.

Akther A, Robinson J (2014) Immigrant students' academic performance in Australia, New Zealand, Canada and Singapore. Brisbane: Joint AARE-NZARE 2014 Conference.

Areepattamannil S, Melkonian M, and Khine MS (2015) International note: Exploring differences in native and immigrant adolescents' mathematics achievement and dispositions towards mathematics in Qatar. Journal of Adolescence, 40: 11-13.

Driessen G, Dekkers H (1997) Educational Opportunities in the Netherlands: Policy, Students' Performance and Issues. International Review of Education, 43: 299315.

Hanushek E, Rivkin S (2010) Generalizations about Using Value-Added Measures of Teacher Quality, American Economic Review, Papers and Proceedings, 100:267271.

Hellenic Regional Development Centre. (2007) European Intercultural Workplace. Available at: http://www.immi.se/eiw/texts/National_Report_Greece.pdf

Marks GN (2006) Accounting for immigrant non-immigrant differences in reading and mathematics in twenty countries. Ethnic and Racial Studies, 28 (5): 925-946.

OECD (2013) PISA 2012 Results: Excellence through Equity (Volume II). Paris: PISA, OECD Publishing.

OECD (2015) Immigrant Students at School: Easing the Journey towards Integration. Paris: OECD Publishing. DOI: http://dx.doi.org/10.1787/9789264249509-en.

Paleologou N (2004) Intercultural education and practice in Greece: needs for bilingual intercultural programmes. Intercultural Education, 15 (3): 317-329.

Pong SL (2009) Grade level and achievement of immigrants' children: academic redshirting in Hong Kong. Educational Research and Evaluation, 15(4): 405-425. 
Rumberger R, Larson K (1998) Student mobility and the increased risk of high school drop-out. American Journal of Education, 107:1-35.

Schnell P, Azzolini D (2015) The academic achievements of immigrant youths in new destination countries: Evidence from southern Europe. Migration Studies, 3(2): 217240.

Schnepf, SV (2007) Immigrants' educational disadvantage: an examination across ten countries and three surveys. Journal of Population Economics, 20: 527-545.

Snijders T, Bosker R (1999) Multilevel Analysis:An Introduction to Basic and Advanced Multilevel Modelling. London: Sage publications.

Stefanidi F, Pavlopoulos V, Obradović J, Dallac M, Takis N, Papathanassiou A and Masten A (2008) Immigration as a risk factor for adolescent adaptation in Greek urban schools. European Journal of Developmental Psychology, 5 (2): 235-261.

Triandafyllidou A (2009) Greek Immigration Policy at the Turn of the 21st Century: Lack of Political Will or Purposeful Mismanagement? European Journal of Migration and Law, 11 (2): 159-177.

Triandafyllidou A, Gropas R (2007) Greek Education Policy and the Challenge of Migration: An Intercultural View of Assimilation. Athens: Helenic Foundation for European and Foreign Policy.

Trouki P, Panagopoulos T (2006) Schools of Intercultural Education. Quantitative data on the school population 1997-2005 (in Greek). Athens: IPODE 